\title{
Can sorafenib be discontinued in hepatocellular carcinoma patients with a complete response to treatment?
}

\author{
Jing Li, Liang Huang, Yi-Qun Yan \\ Department of Hepatic Surgery I, Eastern Hepatobiliary Surgery Hospital, Second Military Medical University, Shanghai 200438, China
}

\section{Address for correspondence:}

Prof. Yi-Qun Yan, Department of Hepatic Surgery I, Eastern Hepatobiliary Surgery Hospital, Second Military Medical University, 225 Changhai Road, Shanghai 200438, China. E-mail: ehbhyyq@163.com

Received: 18-05-2015, Accepted: 24-06-2015

\section{INTRODUCTION}

Sorafenib is a multi-kinase inhibitor that inhibits angiogenesis by targeting the vascular endothelial growth factor receptor 2 and platelet-derived growth factor receptor pathways while blocking cell proliferation by targeting the Ras/mitogen-activated protein kinase signaling pathway. Two global phase III trials [Sorafenib Hepatocellular Carcinoma Assessment Randomized Protocol (SHARP) ${ }^{[1]}$ and Asia-Pacific trial $\left.^{[2]}\right]$ showed that sorafenib prolonged the survival of patients with advanced hepatocellular carcinoma (HCC). The results of these studies were rapidly disseminated worldwide and were enthusiastically accepted by physicians specializing in liver cancer treatment. Based on the positive results of the SHARP trial, ${ }^{[1]}$ the EU and USA approved sorafenib for advanced HCC in October and November 2007, respectively. Sorafenib was also approved for patients with unresectable and metastatic HCC in July 2008 in China, but patients have to pay the cost by themselves.

Thereafter, clinicians studied whether enhanced benefits could be derived from combining sorafenib with other therapeutic means. Several studies ${ }^{[3,4]}$ assessed optimal combinations of sorafenib with transarterial chemoembolization (TACE) or radiofrequency ablation, as well as the sequence of treatment modalities in order to maximize patients' outcomes. Since then, an increasing number of complete remission (CR) cases

\begin{tabular}{|l|c|}
\hline \multicolumn{2}{|c|}{ Access this article online } \\
\hline \multirow{2}{*}{ Website: } & Quick Response Code \\
\hline http://www.hrjournal.net/ & \\
DOI: & 10.4103/2394-5079.161332
\end{tabular}

were reported. ${ }^{[5]}$ For patients who have achieved CR, whether sorafenib can be discontinued remains unknown.

\section{PRESENTATION OF THE HYPOTHESIS}

Most cases in which sorafenib was discontinued during the course of treatment for HCC resulted from severe adverse events. ${ }^{[1,2]}$ For patients who have achieved CR, we proposed the concept that sorafenib may be discontinued in CR cases, taking into consideration the high cost for such patients in poor societies, particularly those in developing countries with restrictive coverage for certain pharmaceuticals from national health insurance systems.

\section{SUPPORTIVE OBSERVATION FOR THIS HYPOTHESIS AND FUTURE DIRECTIONS}

Recently, a 39-year-old male patient who was diagnosed with HCC ( $2 \mathrm{~cm}$ in diameter) on May 6, 2010 was admitted. He could not receive radical therapy (hepatic resection or radiofrequency ablation) because the tumor was located very close to the right branch of the portal vein. Therefore, he received TACE plus sorafenib therapy. One week later, he had severe drug-related diarrhea (4-8 times bowel movement daily). Five weeks after treatment, the tumor was not detected on both computed tomography scan and

This is an open access article distributed under the terms of the Creative Commons Attribution-NonCommercial-ShareAlike 3.0 License, which allows others to remix, tweak, and build upon the work non-commercially, as long as the author is credited and the new creations are licensed under the identical terms.

For reprints contact: reprints@medknow.com

How to cite this article: Li J, Huang L, Yan YQ. Can sorafenib be discontinued in hepatocellular carcinoma patients with a complete response to treatment? Hepatoma Res 2015;1:109-10. 
Table 1: A brief summary of previous reports of CR cases treated with sorafenib as a monotherapy for HCC

\begin{tabular}{lccc}
\hline References & $\begin{array}{c}\text { CR } \\
\text { cases }\end{array}$ & $\begin{array}{c}\text { Duration of } \\
\text { treatment cessation } \\
\text { (months) }\end{array}$ & Relapse \\
\hline So et al. ${ }^{[7]}$ & 1 & 6 & No \\
Kudo and Ueshima ${ }^{[5]}$ & 15 & NA & No \\
Wang et al. ${ }^{[8]}$ & 1 & 16 & No \\
Sacco et $a l .{ }^{[9]}$ & 1 & $\geq 6$ & No \\
Inuzuka et al. ${ }^{[10]}$ & 1 & 8 & No \\
\hline
\end{tabular}

CR: complete remission; HCC: hepatocellular carcinoma; NA: not available

magnetic resonance imaging. Thereafter, he discontinued sorafenib therapy because he could not afford the treatment cost. Up to April 30, 2015, he had CR of tumor status for 58 months.

As we know, most patients treated with tyrosine kinase inhibitors (TKIs) would suffer from drug-related adverse effects. Discontinuation of treatment with TKIs could improve quality-of-life and reduce treatment costs for patients in which a CR is achieved. ${ }^{|6|}$ To our knowledge, there are several case reports concerning this issue [Table 1], and it seems that relapse of tumor hardly happens in patients who have achieved CR after sorafenib monotherapy, irrespective of drug discontinuation or not. For patients who received sorafenib in combination with other therapeutic means, the CR status may be partly due to the combination treatment, like TACE. Therefore, we propose that sorafenib should be discontinued to reduce the drug-related adverse effects. However, discontinuation of sorafenib in patients with CR carries the risk of progression with new metastases and potential complications. Further investigation in a larger cohort of cases is warranted before such an approach can be regarded as safe. However, this methodology has limitations associated with the small sample of CR cases and interference of other therapeutic means, and hence it may just be a hypothesis.

\section{CONCLUSION}

Sorafenib has demonstrated clinical efficacy in HCC patients, and more and more CR cases were reported. For patients who have achieved $\mathrm{CR}$, we propose that sorafenib may be discontinued, irrespective of whether it was used as monotherapy or combination therapy with other therapeutic means. Evaluation of the current hypothesis and investigation with a larger cohort of cases may provide information that such an approach can be regarded as safe, and thereby improves quality-of-life and reduces treatment costs for patients in which a CR is achieved.

\section{Financial support and sponsorship \\ Nil.}

\section{Conflict of interest}

There is no conflict of interest.

\section{REFERENCES}

1. Llovet JM, Ricci S, Mazzaferro V, Hilgard P, Gane E, Blanc JF, de Oliveira AC, Santoro A, Raoul JL, Forner A, Schwartz M, Porta C, Zeuzem S, Bolondi L, Greten TF, Galle PR, Seitz JF, Borbath I, Häussinger D, Giannaris T, Shan M, Moscovici M, Voliotis D, Bruix J; SHARP Investigators Study Group. Sorafenib in advanced hepatocellular carcinoma. N Engl J Med 2008;359:378-90.

2. Cheng AL, Kang YK, Chen Z, Tsao CJ, Qin S, Kim JS, Luo R, Feng J, Ye S, Yang TS, Xu J, Sun Y, Liang H, Liu J, Wang J, Tak WY, Pan H, Burock K, Zou J, Voliotis D, Guan Z. Efficacy and safety of sorafenib in patients in the Asia-Pacific region with advanced hepatocellular carcinoma: a phase III randomised, double-blind, placebo-controlled trial. Lancet Oncol 2009;10:25-34.

3. Zhang L, Hu P, Chen X, Bie P. Transarterial chemoembolization (TACE) plus sorafenib versus TACE for intermediate or advanced stage hepatocellular carcinoma: a meta-analysis. PLoS One 2014;9:e100305.

4. Chao Y, Chung YH, Han G, Yoon JH, Yang J, Wang J, Shao GL, Kim BI, Lee TY. The combination of transcatheter arterial chemoembolization and sorafenib is well tolerated and effective in Asian patients with hepatocellular carcinoma: final results of the START trial. Int J Cancer 2015;136:1458-67.

5. Kudo M, Ueshima K. Positioning of a molecular-targeted agent, sorafenib, in the treatment algorithm for hepatocellular carcinoma and implication of many complete remission cases in Japan. Oncology 2010;78 Suppl 1:154-66.

6. Johannsen M, Flörcken A, Bex A, Roigas J, Cosentino M, Ficarra V, Kloeters C, Rief M, Rogalla P, Miller K, Grünwald V. Can tyrosine kinase inhibitors be discontinued in patients with metastatic renal cell carcinoma and a complete response to treatment? A multicentre, retrospective analysis. Eur Urol 2009;55:1430-8.

7. So BJ, Bekaii-Saab T, Bloomston MA, Patel T. Complete clinical response of metastatic hepatocellular carcinoma to sorafenib in a patient with hemochromatosis: a case report. J Hematol Oncol 2008;1:18.

8. Wang SX, Byrnes A, Verma S, Pancoast JR, Rixe O. Complete remission of unresectable hepatocellular carcinoma treated with reduced dose of sorafenib: a case report. Target Oncol 2010;5:59-63.

9. Sacco R, Bargellini I, Gianluigi G, Bertini M, Bozzi E, Altomare E, Battaglia V, Romano A, Bertoni M, Capria A, Bresci G, Bartolozzi C. Complete response for advanced liver cancer during sorafenib therapy: case report. BMC Gastroenterol 2011;11:4.

10. Inuzuka T, Nishikawa H, Sekikawa A, Takeda H, Henmi S, Sakamoto A, Saito S, Kita R, Kimura T, Osaki Y, Kudo M. Complete response of advanced hepatocellular carcinoma with multiple lung metastases treated with sorafenib: a case report. Oncology 2011;81 Suppl 1:152-7. 